\title{
Assessment of premature mortality for noncommunicable diseases
}

\author{
Avaliação da mortalidade prematura por doença crônica não transmissível \\ Evaluación de la mortalidad prematura para la enfermedad crónica no transmisible
}

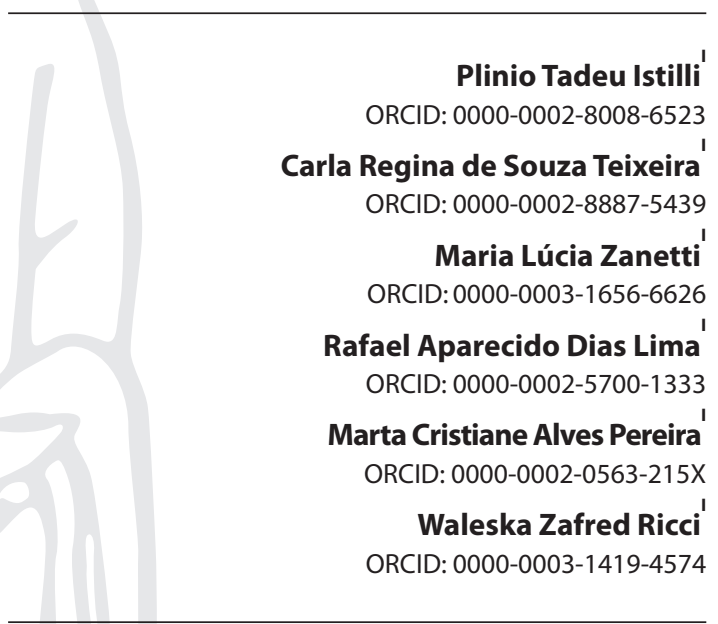

'Universidade de São Paulo. Ribeirão Preto, São Paulo, Brazil.

How to cite this article: Istilli PT, Teixeira CRS, Zanetti ML, Lima RAD, Pereira MCA, Ricci WZ. Avaliação da mortalidade prematura por doença crônica não transmissível. Rev Bras Enferm. 2020;73(2):e20180440. doi: http://dx.doi.org/10.1590/0034-7167-2018-0440

\section{Corresponding Author: \\ Carla Regina de Souza Teixeira}

E-mail: carlarst@eerp.usp.br

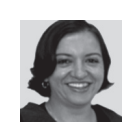

EDITOR IN CHIEF: Dulce Aparecida Barbosa ASSOCIATE EDITOR: Hugo Fernandes

Submission: 06-09-2018

Approval: 09-23-2018

\begin{abstract}
Objectives: to analyze premature mortality and Potential Years of Life Lost by noncommunicable diseases in a city in the countryside of São Paulo from 2010 to 2014. Methods: ecological study of temporal tendency, using secondary source. For analysis, the premature mortality coefficient and the Potential Years of Life Lost indicator were used. Results: males had the highest premature mortality rate due to cardiovascular disease, with 213.04 deaths per 100 thousand inhabitants, followed by neoplasms, with 188.44. In women, there was an inversion with 134.22 deaths from cancer and 110.71 deaths from cardiovascular disease. Regarding Potential Years of Life Lost, males had an average of 12.19 years lost by death and females of 13.45 years lost. Conclusions: the results reinforce the need to increase public health prevention and promotion policies to reduce premature deaths, especially among men.

Descriptors: Chronic Disease; Mortality; Mortality, Premature; Potential Years of Life Lost; Gender and Health.
\end{abstract}

\section{RESUMO}

Objetivos: analisar a mortalidade prematura e os Anos Potenciais de Vida Perdidos por doenças crônicas não transmissíveis, em uma cidade do interior de São Paulo, no período de 2010 a 2014. Métodos: estudo ecológico, de tendência temporal, utilizando-se fonte secundária. Para análise, utilizou-se o coeficiente de mortalidade prematura e indicador de Anos Potenciais de Vida Perdidos. Resultados: o sexo masculino apresentou maior coeficiente de mortalidade prematura por doença cardiovascular, com 213,04 óbitos por 100 mil habitantes, seguido por neoplasias, com 188,44. Nas mulheres, houve uma inversão com 134,22 óbitos por neoplasias e 110,71 óbitos causados pelas doenças cardiovasculares. Em relação aos Anos Potenciais de Vida Perdidos, o sexo masculino apresentou média de 12,19 anos perdidos por óbito e o sexo feminino de 13,45 anos perdidos. Conclusões: os resultados reforçam a necessidade de incrementar políticas públicas de prevenção e promoção de saúde para redução de mortes prematuras, em especial dos homens.

Descritores: Doença Crônica; Mortalidade; Mortalidade Prematura; Anos Potenciais de Vida Perdidos; Gênero e Saúde.

\section{RESUMEN}

Objetivos: analizar la mortalidad prematura y los Años Potenciales de Vida Perdidos por enfermedades crónicas no transmisibles en una ciudad del interior de São Paulo, de 2010 a 2014. Métodos: Estudio ecológico de tendencia temporal, utilizando fuente secundaria. Para el análisis, se utilizaron el coeficiente de mortalidad prematura y el indicador de Años Potenciales de Vida Perdidos. Resultados: los hombres tuvieron la tasa de mortalidad prematura más alta debido a enfermedades cardiovasculares, con 213.04 muertes por cada 100 mil habitantes, seguidos de neoplasias, con 188.44. En las mujeres, hubo una inversión con 134.22 muertes por cáncer y 110.71 muertes por enfermedad cardiovascular. Con respecto a los posibles Años Potenciales de Vida Perdidos, los hombres tenían un promedio de 12,19 años perdidos por muerte y las mujeres de 13,45 años perdidos. Conclusiones: los resultados refuerzan la necesidad de aumentar la prevención pública y las políticas de promoción de la salud para reducir las muertes prematuras, especialmente entre los hombres. Descriptores: Enfermedad Crónica; Mortalidad; Mortalidad Prematura; Años Potenciales de Vida Perdidos; Género y Salud. 
Assessment of premature mortality for noncommunicable diseases Istilli PT, Teixeira CRS, Zanetti ML, Lima RAD, Pereira MCA, Ricci WZ.

\section{INTRODUCTION}

In recent decades, there has been a process of epidemiological transition, with repercussions on world health ${ }^{(1)}$. Epidemiological transition is a broad process that changes the pattern of population morbidity and mortality and is usually accompanied by other demographic, socioeconomic, technological and nutritional processes ${ }^{(1)}$. Moreover, mortality burden was reversed by infectious diseases that in the past accounted for high mortality rates, non-communicable diseases (NCDs), which are currently the leading causes of death and disability ${ }^{(1)}$.

In 201238 million (68\%) of deaths were attributed to NCDs, and 16.2 million (42\%) were due to premature and preventable deaths, that is, individuals under 70 years of age ${ }^{(2)}$. Cardiovascular diseases, neoplasms, chronic respiratory diseases, and diabetes mellitus (DM) represent the group of NCDs with higher mortality rates. These diseases account for 31 million (82\%) of NCD deaths and 12.2 million (75\%) of premature deaths. 17.5 million (46.2\%) of deaths are caused by cardiovascular disease; 6 million (37\%) of premature deaths from NCDs; neoplasms are responsible for 8.2 (21.7\%) million deaths; 4.3 million (27\%) of premature deaths are caused by NCDs. Chronic respiratory diseases account for 4 million (10.7\%) deaths - with 1.3 million (8\%) of premature NCD deaths. Finally, DM accounts for 1.5 million (4\%) deaths - 650,000 (4\%) of premature NCD deaths ${ }^{(2-3)}$.

Cardiovascular diseases, neoplasms, chronic respiratory diseases, and DM represent the group of NCDs with the highest mortality rates. These diseases account for 31 million (82\%) of deaths and 12.2 million (75\%) of premature deaths, with 17.5 million (46.2\%) triggered by cardiovascular disease and six million (37\%) by neoplasms, chronic respiratory diseases, and $\mathrm{DM}^{(2-3)}$.

In Brazil, epidemiological transition has shown that NCDs are one of the public health problems ${ }^{(1)}$. In 2011 they accounted for $800,118(72.7 \%)$ of deaths. According to the World Health Organization (WHO), cardiovascular diseases, neoplasms, chronic respiratory diseases and DM accounted for 640,156 (80\%) of deaths, with cardiovascular diseases leading the ranking of deaths from NCDs, followed by neoplasms, chronic respiratory diseases, and $\mathrm{DM}^{(4)}$. In the same year, these four chronic diseases were attributed to 289,927 (36.2\%) premature deaths, especially in the Southeast, where 140,864 (48\%) premature deaths occurred ${ }^{(5)}$.

In this regard, public policies were designed and implemented to address NCDs, with targets set for reducing premature mortality. It should be noted that WHO has made available the Global Action Plan for the Prevention and Control of Noncommunicable Diseases. This plan recommends targeting $25 \%$ reduction in premature NCD death by $2025^{(6)}$. Accordingly, the Brazilian Ministry of Health has proposed the Strategic Action Plan for Coping with NCDs 2011-2022 (Ações Estratégicas para o Enfrentamento das DCNTs 2011-2022). This plan also aimed to reduce the premature mortality rate by $2 \%$ per year in Brazil(7-8).

Given the above, considering the scarcity of literature in Brazil on premature mortality from NCDs in Brazil, we propose to carry out the present investigation. This study is expected to provide input for the monitoring of premature NCD mortality.

\section{OBJECTIVES}

To analyze premature mortality and Potential Years of Life Lost (PYLL) by NCDs in a city in the countryside of São Paulo from 2010 to 2014.

\section{METHODS}

\section{Ethical aspects}

The study was approved by the Research Ethics Committee (REC) of Escola de Enfermagem de Ribeirão Preto.

\section{Design, place of study and period}

This is an ecological and temporal-trend study in a city in the countryside of the state of São Paulo, Brazil, from 2010 to 2014, located in the northeast. The city is $313 \mathrm{~km}$ from the capital, having an area of $650 \mathrm{~km}^{2}$ and a population of 604,682 thousand, according to the 2010 census $^{(9)}$.

\section{Sampling; inclusion and exclusion criteria}

The study population consisted of the 12,956 deaths from NCDs from 2010 to 2014, in the city of Ribeirão Preto, São Paulo, provided by the Epidemiological Surveillance Division of Ribeirão Preto's Municipal Office. The four main chronic diseases were extracted from the database, responsible for 11,865 deaths (cardiovascular (I00-199), neoplasms (C00-C97), chronic respiratory diseases (J30J97) and DM (E10-E14)) $)^{(2)}$. Deaths of people living in Ribeirão Preto and regardless of place of death were inclusion criteria. A total of 7,103 deaths were extracted for age $\leq 29$ years or $\geq 70$ years old $^{(2)}$. Thus, the sample consisted of 4,762 deaths of people aged 30 to 69 years, and cardiovascular diseases, neoplasms, chronic respiratory diseases, and DM during the study period.

\section{Study protocol}

The variables sex and underlying cause of death were chosen. To collect these variables, we used TABWIN version $3.6 \mathrm{~b}$, a program developed for use on the Windows platform version 10, prepared by DATASUS (computer department of the Brazilian Unified Health System (Sistema Único de Saúde)). Using this tool facilitated tabulation and data processing. The collected data were imported into Excel spreadsheets, allowing statistical analysis.

\section{Analysis of results, and statistics}

For data presentation, descriptive statistics using the number and total percentage of premature deaths from NCDs were used. To calculate the standardized coefficients of premature mortality, the methodology proposed by the World Health Organization ${ }^{(10)}$.

To calculate the PYLL indicator, the age limit of 70 years was subtracted from the age at which death occurred. This indicator quantifies the number of years of life not lived when death occurs at a certain age below which premature death is considered. For this study, the age of 70 years was established. This method was 
proposed by Romender and McWhinnie ${ }^{(11)}$. The standardized PYLL coefficient was calculated using the same methodology as the premature mortality coefficient ${ }^{(10)}$. Finally, to calculate the premature mortality ratio and PYLL, the numerator used was male, and denominator, female. A ratio of 1 suggests that men and women have the same coefficient. The higher the ratio, the greater the male disadvantage. If the ratio is less than 1, female coefficients are greater than male ones ${ }^{(12)}$.

\section{RESULTS}

Of the 4,762 premature deaths due to cardiovascular disease, neoplasms, chronic respiratory diseases and DM, from 2010 to 2014, 2,805 were male and 1,957 were female, as shown in Table 1.

When analyzing premature mortality coefficients for males, there is a homogeneous distribution in the results, with the highest value being in 2014. For females, there was greater variation in premature mortality coefficients, also in 2014. Males presented higher death values for cardiovascular diseases, and women, due to cancer, in 2012. The results obtained by the premature mortality ratio show that the values found were greater than one. This shows that male mortality is higher than female mortality. The highest values obtained by the premature mortality ratio were for respiratory diseases in 2012 and 2013 (Table 2).

Of the 4,762 premature deaths, the number of PYLL by NCDs was 56,957 years, being higher for males. Table 3 shows that the average PYLL per death was 11.96 years.

In the five years of study, when analyzing the PYLL coefficients for cardiovascular diseases, neoplasms, chronic respiratory diseases and DM, the highest coefficient was obtained for males in 2010, with emphasis on cardiovascular diseases in 2013. For females, the highest PYLL coefficient was for neoplasms in 2012. Values greater than one in the premature mortality ratio and PYLL show that males had more PYLL compared to females. The ratio was greater than two at eight times, so males had twice as much PYLL as females for investigated chronic diseases (Table 4).

Table 1 - Absolute number and percentage of premature deaths according to sex and non-communicable diseases from 2010 to 2014 , Ribeirão Preto, São Paulo, Brazil, 2018

\begin{tabular}{|c|c|c|c|c|c|c|c|}
\hline \multirow{2}{*}{$\begin{array}{l}\text { Noncommunicable } \\
\text { Diseases }\end{array}$} & \multirow{2}{*}{ ICD-10 } & \multicolumn{2}{|c|}{ Male Premature Deaths } & \multicolumn{2}{|c|}{$\begin{array}{c}\text { Female Premature } \\
\text { Deaths }\end{array}$} & \multicolumn{2}{|c|}{ Total } \\
\hline & & $\mathbf{n}$ & $\%$ & $\mathbf{n}$ & $\%$ & $\mathbf{n}$ & $\%$ \\
\hline Cardiovascular Diseases & $100-199$ & 1.343 & 47.88 & 814 & 41.59 & 2.157 & 45.30 \\
\hline Neoplasms & $\mathrm{C} 00-\mathrm{C} 97$ & 1.145 & 40.82 & 924 & 47.22 & 2.069 & 43.45 \\
\hline Respiratory Diseases & J30-J98 & 187 & 6.67 & 118 & 6.03 & 305 & 6.40 \\
\hline DM & E10-E14 & 130 & 4.63 & 101 & 5.16 & 231 & 4.85 \\
\hline Total & & 2.805 & 100.00 & 1.957 & 100.00 & 4.762 & 100.00 \\
\hline
\end{tabular}

Source: Epidemiological Surveillance Division of Ribeirão Preto's Municipal Office - SP. Note: DM - diabetes mellitus.

Table 2 - Premature mortality rates by non-communicable diseases according to sex and ratio of coefficients between males and females from 2010 to 2014, Ribeirão Preto, São Paulo, Brazil, 2018

\begin{tabular}{|c|c|c|c|c|c|c|c|c|c|c|c|c|c|c|c|c|}
\hline \multirow{2}{*}{$\begin{array}{l}\text { Noncommunicable } \\
\text { Diseases }\end{array}$} & \multirow[b]{2}{*}{ ICD-10 } & \multicolumn{3}{|c|}{2010} & \multicolumn{3}{|c|}{2011} & \multicolumn{3}{|c|}{2012} & \multicolumn{3}{|c|}{2013} & \multicolumn{3}{|c|}{2014} \\
\hline & & $M^{*}$ & $F^{*}$ & $\begin{array}{l}\text { Ratio } \\
\text { M/F }\end{array}$ & $M^{*}$ & $\mathbf{F}^{*}$ & $\begin{array}{l}\text { Ratio } \\
\text { M/F }\end{array}$ & $M^{*}$ & $F^{*}$ & $\begin{array}{l}\text { Ratio } \\
\text { M/F }\end{array}$ & $M^{*}$ & $\mathbf{F}^{*}$ & $\begin{array}{l}\text { Ratio } \\
\text { M/F }\end{array}$ & $M^{*}$ & $\mathbf{F}^{*}$ & $\begin{array}{l}\text { Ratio } \\
\text { M/F }\end{array}$ \\
\hline Cardiovascular Diseases & $100-199$ & 212.70 & 110.71 & 1.92 & 211.54 & 108.95 & 1.94 & 213.04 & 106.39 & 2.00 & 206.49 & 97.82 & 2.11 & 209.69 & 103.90 & 2.02 \\
\hline Neoplasms & $\mathrm{C} 00-\mathrm{C} 97$ & 179.73 & 102.62 & 1.75 & 171.84 & 99.82 & 1.72 & 182.94 & 134.22 & 1.36 & 179.54 & 126.11 & 1.42 & 188.44 & 133.20 & 1.41 \\
\hline Respiratory Diseases & J30-J98 & 28.58 & 17.71 & 1.61 & 30.53 & 16.77 & 1.82 & 29.29 & 11.74 & 2.50 & 36.45 & 14.03 & 2.60 & 21.98 & 16.12 & 1.36 \\
\hline DM & E10-E14 & 17.55 & 13.12 & 1.34 & 20.28 & 9.68 & 2.10 & 18.62 & 14.16 & 1.31 & 21.03 & 11.23 & 1.87 & 24.29 & 19.72 & 1.23 \\
\hline Total & & 438.56 & 244.17 & 1.80 & 434.19 & 235.22 & 1.85 & 443.88 & 266.51 & 1.67 & 443.51 & 249.20 & 1.78 & 444.40 & 272.94 & 1.63 \\
\hline
\end{tabular}

Source: Epidemiological Surveillance Division of Ribeirão Preto's Municipal Office - SP.

Note: *Coefficients per 100 thousand inhabitants; DM - diabetes mellitus.

Table 3 - Number of Potential Years of Life Lost, percentage and mean by death by sex and non-communicable diseases from 2010 to 2014 , Ribeirão Preto, São Paulo, Brazil, 2018

\begin{tabular}{|c|c|c|c|c|c|c|c|c|c|c|}
\hline \multirow{2}{*}{$\begin{array}{l}\text { Noncommunicable } \\
\text { Diseases }\end{array}$} & \multirow{2}{*}{ ICD-10 } & \multicolumn{3}{|c|}{ Male } & \multicolumn{3}{|c|}{ Female } & \multicolumn{3}{|c|}{ Total } \\
\hline & & PYLL & $\%$ & Per death & PYLL & $\%$ & Per death & PYLL & $\%$ & Per death \\
\hline Cardiovascular Diseases & $100-199$ & 16.370 & 49.02 & 12.19 & 8.955 & 38.01 & 11.00 & 25.325 & 44.46 & 11.74 \\
\hline Neoplasms & $\mathrm{C} 00-\mathrm{C} 97$ & 13.400 & 40.13 & 11.70 & 12.430 & 52.75 & 13.45 & 25.830 & 45.35 & 12.26 \\
\hline Respiratory Diseases & J30-J98 & 2.221 & 6.65 & 11.88 & 1.182 & 5.02 & 10.01 & 3.403 & 5.97 & 11.15 \\
\hline DM & E10-E14 & 1.404 & 4.20 & 10.80 & 995 & 4.22 & 9.85 & 2.399 & 4.21 & 10.38 \\
\hline Total & & 33.395 & 100.00 & 11.90 & 23.562 & 100.00 & 12.03 & 56.957 & 100.0 & 11.96 \\
\hline
\end{tabular}

Source: Epidemiological Surveillance Division of Ribeirão Preto's Municipal Office.

Note: DM - diabetes mellitus; PYLL - Potential Years of Life Lost. 
Table 4 - Potential Years of Life Lost coefficients by non-communicable diseases according to sex and ratio of coefficients between males and females from 2010 to 2014, Ribeirão Preto, São Paulo, Brazil, 2018

\begin{tabular}{|c|c|c|c|c|c|c|c|c|c|c|c|c|c|c|c|c|}
\hline \multirow{2}{*}{$\begin{array}{l}\text { Noncommunicable } \\
\text { Diseases }\end{array}$} & \multirow[b]{2}{*}{ ICD-10 } & \multicolumn{3}{|c|}{2010} & \multicolumn{3}{|c|}{2011} & \multicolumn{3}{|c|}{2012} & \multicolumn{3}{|c|}{2013} & \multicolumn{3}{|c|}{2014} \\
\hline & & $\mathbf{M}^{*}$ & $\mathbf{F}^{*}$ & $\begin{array}{c}\text { Ratio } \\
\text { M/F }\end{array}$ & $\mathbf{M}^{*}$ & $F^{*}$ & $\begin{array}{c}\text { Ratio } \\
\text { M/F }\end{array}$ & $\mathbf{M}^{*}$ & $\mathbf{F}^{*}$ & $\begin{array}{c}\text { Ratio } \\
\text { M/F }\end{array}$ & $\mathbf{M}^{*}$ & $F^{*}$ & $\begin{array}{c}\text { Ratio } \\
\text { M/F }\end{array}$ & $M *$ & $\mathbf{F}^{*}$ & $\begin{array}{c}\text { Ratio } \\
\text { M/F }\end{array}$ \\
\hline $\begin{array}{l}\text { Cardiovascular } \\
\text { Diseases }\end{array}$ & $100-199$ & 2.522 .99 & $1,146.82$ & 2.20 & $2,451.83$ & $1,267.73$ & 1.93 & $2,308.84$ & $1,227.89$ & 1.88 & $2,543.30$ & 993.57 & 2.56 & $2,361.48$ & $1,105.61$ & 2.14 \\
\hline Neoplasms & $\mathrm{COO}-\mathrm{C} 97$ & 2.139 .87 & $1,354.20$ & 1.58 & $1,860.83$ & $1,485.49$ & 1.25 & $1,945.85$ & $1,837.38$ & 1.06 & $2,029.35$ & $1,514.69$ & 1.34 & $2,035.18$ & $1,803.93$ & 1.13 \\
\hline Respiratory Diseases & J30-J98 & 307.91 & 107.53 & 2.86 & 360.19 & 205.41 & 1.75 & 357.21 & 117.32 & 3.04 & 380.04 & 165.26 & 2.30 & 184.63 & 157.51 & 1.17 \\
\hline DM & E10-E14 & 193.96 & 134.21 & 1.45 & 204.24 & 91.40 & 2.23 & 202.89 & 146.85 & 1.38 & 200.48 & 86.59 & 2.32 & 262.17 & 186.56 & 1.41 \\
\hline Total & & 5.164 .57 & $2,742.95$ & 1.88 & $4,876.80$ & $3,050.25$ & 1.60 & $4,814.90$ & $3,329.44$ & 1.45 & $5,153.17$ & $2,760.11$ & 1.87 & $4,843.46$ & $3,253.60$ & 1.49 \\
\hline
\end{tabular}

Source: Epidemiological Surveillance Division of Ribeirão Preto's Municipal Office.

Nota: *Coefficients per 100 thousand inhabitants; DM - diabetes mellitus.

\section{DISCUSSION}

Analyzing the results, it was verified that there were differences between the premature mortality coefficient and the PYLL in relation to sex by NCDs, from 2010 to 2014. Cardiovascular diseases and neoplasms were the main causes of premature mortality in both groups. sexes, accounting for $45.30 \%$ and $43.45 \%$ of deaths, respectively, and males had higher values when compared to females.

For males, cardiovascular diseases were the most prevalent causes of death, and $47.88 \%$ were attributed to premature deaths, followed by neoplasms (40.82\%). In contrast, for females, there is an inversion, with premature deaths from cancer being the most prevalent (47.22\%), followed by cardiovascular disease (41.59\%). These data are similar to a nationwide study showing that the percentage of premature deaths in men due to cardiovascular disease is higher than those due to cancer. This study also pointed out that, for females, premature deaths from cancer were higher than those from cardiovascular disease from 2000 to $2011^{(13)}$.

When analyzing the premature mortality coefficients for cardiovascular diseases, a higher value was obtained for males, and the highest coefficient found was in 2012. Studies show values of premature mortality coefficient for similar cardiovascular diseases, that is, higher in men than in women ${ }^{(13-15)}$.

Regarding neoplasms, it was found that they accounted for almost half of premature deaths due to cardiovascular diseases, neoplasms, respiratory diseases and DM in females. Regarding sex, men and women presented an increase in the premature mortality coefficient due to cancer. In contrast, other studies have shown that cancer mortality remained stable across all age groups in Brazil from 1990 to $2015^{(16)}$. There was a trend towards a reduction in premature mortality for both sexes from 2000 to $2011^{(13)}$.

Regarding respiratory diseases, there was a reduction in the premature mortality coefficient for both sexes. On the other hand, one study showed a reduction for females and a stationary coefficient for males ${ }^{(13)}$, and another, a reduction trend for both sexes from 1996 to $2010^{(15)}$.

Regarding DM, the premature mortality coefficient for males was higher than for females. However, when analyzing the period investigated, it was found that there was a trend of increase for females. These results are inconsistent with a Brazilian study that showed that there was no change in premature mortality in males, but a reduction in females between 2000 and $2011^{(13)}$.

Increased premature mortality coefficient due to cardiovascular diseases, neoplasms, respiratory diseases, and DM, in Ribeirão Preto, during the study period, was $1.32 \%$ for males and $11.79 \%$ for females. These results fall short of the goal advocated by the Ministry of Health, that is, a $2 \%$ reduction per year, as recommended in the NCDs Coping Plan ${ }^{(7)}$.

Considering that the results show that the ratio of the premature mortality coefficient is higher in males than in females for NCDs, it is necessary to rethink public policies for this most vulnerable population. A Brazilian study showed that the probability of dying between 30 and 70 years old due to cardiovascular diseases, neoplasms, respiratory diseases and DM decreased from $32.3 \%$ to $22.8 \%$ between 1993 and 2010 for males, and from 23.5\% to $15.4 \%$ in females. It is noteworthy that, even with this reduction, mortality in males always presents higher values than in females ${ }^{(15)}$. In this direction, investments in public policies should be increased to reduce the impact of modifiable risk factors such as alcohol and tobacco consumption, unbalanced diet and physical inactivity in reducing premature mortality rates in the city ${ }^{(6-7)}$.

By analyzing these diseases, a loss of 11.96 PYLL was obtained for each death, and the neoplasm that causes the most PYLL. As for sex, the biggest impact was for females. These results may be related to increased life expectancy of the population, especially in females, added to the increased exposure to risk factors for malignancy onset ${ }^{(16)}$.

For cardiovascular diseases, the PYLL coefficient showed a difference between sexes in 2014, and males presented a coefficient twice higher than females. An American study showed that after acute myocardial infarction, males lose an average of $41.8 \%$ of remaining years of life, while females only lose $10.5 \%$. This shows that even being in a developed country, the potential lost years of life are higher in males ${ }^{(17)}$.

For the PYLL coefficient for cancer, there was a decline of $4.9 \%$ for males and an increase of $33.20 \%$ for females. A study conducted in Colombia on premature mortality shows that from 1997 to 2012 the total PYLL for cancer increased, being higher in women than in men ${ }^{(18)}$.

When analyzing the PYLL coefficient in relation to DM, there was an increase of $35.15 \%$ in males and $39.04 \%$ in females in relation to cardiovascular diseases, neoplasms, and respiratory 
diseases. These differences were also found in a study conducted in England, where women had potentially lost six years of life and men five years compared to people without $\mathrm{DM}^{(19)}$.

A study conducted in Mexico also showed that DM was the leading cause of premature death, being higher in men than in women ${ }^{(20)}$. Another national study conducted over a 12-month period showed that chronic complications of type $2 \mathrm{DM}$ accounted for $80 \%$ of PYLL ${ }^{(21)}$.

The premature mortality and PYLL ratios of men to women were higher than one in each year, thus evidencing that males died more often than women for all NCDs and in eight moments The number of male deaths represented twice the female death.

There is a scarcity of studies on premature mortality in national and international literature using the PYLL indicator for cardiovascular diseases, neoplasms, respiratory diseases, and DM. It is worth noting that this indicator is more used in studies of mortality due to external cause, maternal mortality, among others ${ }^{(22)}$.

\section{Study limitations}

Premature mortality timeframe and data reliability in the Mortality Information System's second database may be limits for the present investigation.

\section{Contributions to nursing, health or public policy}

The results of the study allowed us to establish the diagnosis regarding premature mortality from cardiovascular diseases, neoplasms, respiratory diseases and DM in Ribeirão Preto. The increase in mortality coefficients added to the increase in the total of PYLL allows health professionals to rethink the effectiveness of public prevention and health promotion policies to reduce premature deaths, especially in males. Thus, there is a need for actions focused on men's health regarding access to health services, and for women, the increase of preventive exams to reduce cancer. For nursing, we highlight the demand for self-care education for vulnerable groups in order to contribute to achieving the Ministry of Health's goals in reducing premature mortality.

\section{CONCLUSIONS}

Of the 4762 premature deaths from NCDs investigated, 2805 were male and 1957 female. Males had higher death rates for cardiovascular diseases and females due to neoplasms. The total PYLL number was 56,957 days and 11,96 years due to premature death. Males have twice as much PYLL as females for investigated chronic diseases.

\section{FUNDING}

To CNPq, for granting the scholarship case number: 164427 / 2015-5, Modality - Category: Doctorate - GD.

\section{ACKNOWLEDGMENT}

Acknowledgment by the Ribeirão Preto School of Nursing / USP and the members of the EERP / USP Nursing and Diabetes Mellitus Research Group and the Epidemiological Surveillance team of the Ribeirão Preto Health Department - SP.

\section{REFERENCES}

1. Souza MFM, Malta DC, França EB, Barreto ML. Changes in health and disease in Brazil and its States in the 30 years since the Unified Healthcare System (SUS) was created. Ciênc Saúde Colet. 2018;23(6):1737-50. doi: 10.1590/1413-81232018236.04822018

2. World Health Organization (WHO). Global status report on noncommunicable diseases 2014 [Internet]. Geneva: WHO; 2014 [cited 2018 May 23]. Available from: http://apps.who.int/iris/bitstream/handle/10665/148114/9789241564854_eng.pdf;jsessionid=270C4B4F9FFB5EFB42BE 5721D01FF290?sequence $=1$

3. World Health Organization (WHO). World health statistics 2016: monitoring health for the SDGs, sustainable development goals [Internet]. Geneva:WHO; 2016 [cited 2018 May 23]. Available from: http://www.who.int/gho/publications/world_health_statistics/2016/en/

4. Malta DC, Moura L, Prado RR, Escalante JC, Schmidt MI, Duncan BB. Mortalidade por doenças crônicas não transmissíveis no Brasil e suas regiões, 2000 a 2011. Epidemiol Serv Saude. 2014;23(4):599-608. doi: 10.5123/S1679-49742014000400002

5. Ministério da Saúde (BR). Departamento de Informática do SUS (DATASUS). Indicadores Regionais, Estaduais e Nacionais do rol de diretrizes, objetivos, metas e indicadores [Internet]. Brasília: Ministério da Saúde; 2015 [cited 2018 May 23]. Available from: http://datasus.saude. gov.br/11-informacoes-de-saude/indicadores-de-saude-e-pactuacoes/1103-rol-de-diretrizes-objetivos-metas-e-indicadores-2013-2015edicao-2015

6. World Health Organization (WHO). WHO Global action plan for the prevention and control of noncommunicable disease 2013-2020 [Internet]. Geneva:WHO; 2013 [cited 2017 Oct 31]. Available from: http://www.who.int/nmh/events/ncd_action_plan/en/

7. Ministério da Saúde (BR). Secretaria de Vigilância em Saúde. Departamento de Análise de Situação de Saúde. Plano de ações estratégicas para o enfrentamento das Doenças Crônicas Não Transmissíveis (DCNT) no Brasil 2011-2022 [Internet]. Brasília: Ministério da Saúde; 2011 [cited 2017 Oct 31]. Available from: http://bvsms.saude.gov.br/publicacoes/plano_acoes_enfrent_dcnt_2011.pdf

8. Malta DC, Oliveira TP, Santos MAS, Andrade SSCA, Silva MMA; Grupo Técnico de Monitoramento do Plano de DCNT. Progress with the Strategic Action Plan for Tackling Chronic Non-Communicable Diseases in Brazil, 2011-2015. Epidemiol Serv Saúde. 2016;25(2):373-90. doi: $10.5123 / \mathrm{s} 1679-49742016000200016$

9. Instituto Brasileiro de Geografia e Estatística (IBGE). Censo Demográfico 2010 [Internet]. Brasília: IBGE; 2010 [cited 2017 Dec 30]. Available from: https://censo2010.ibge.gov.br/ 
10. Ahmad O, Boschi-Pinto C, Lopez A, Murray C, Lozano R, Inoue M. Age standardization of rates: a new WHO standard [Internet]. Geneva: World Health Organization; 2001 [cited 2018 May 20]. Available from: http://www.who.int/healthinfo/paper31.pdf

11. Romeder JM, McWhinnie JR. Potencial years of life lost between ages 1 and 70: an indicator of premature mortality for health planning. Int J Epidemiol. 1977;6(2):143-51. doi: 10.1093/ije/6.2.143

12. Wisser $\mathrm{O}$, Vaupel JW. The sex differential in mortality: a historical comparison of the adult-age pattern of the ratio and the difference. MPIDR Working Paper WP-2014-005 [Internet]. Rostock: Max Planck Institute for Demographic Research; 2014 [cited 2018 May 20]. Available from: https://www.demogr.mpg.de/papers/working/wp-2014-005.pdf

13. Alves CG, Morais Neto OL. Tendência da mortalidade prematura por doenças crônicas não transmissíveis nas unidades federadas brasileiras. Ciênc Saúde Colet. 2015;20(3):641-54. doi: 10.1590/1413-81232015203.15342014

14. Lotufo PA. Cardiovascular diseases in Brazil: premature mortality, risk factors and priorities for action. Comments on the preliminary results from the Brazilian National Health Survey (PNS), 2013. Sao Paulo Med J. 2015;133(2):69-72. doi: 10.1590/1516-3180.2015.13320018

15. Stevens A, Schmidt MI, Duncan BB. Gender inequalities in non communicable disease mortality in Brazil. Ciênc Saúde Colet. 2012;17(10):2627-34. doi: 10.1590/S1413-81232012001000012

16. Guerra MR, Bustamante-Teixeira MT, Corrêa CSL, Abreu DMX, Curado MP, Mooney M, et al. Magnitude and variation of the burden of cancer mortality in Brazil and Federation Units, 1990 and 2015. Rev Bras Epidemiol. 2017;20(Suppl1):102-15. doi: 10.1590/1980-5497201700050009

17. Jack VT. Life expectancy and years of potential life lost: useful outcome measures in cardiovascular medicine? J Am Coll Cardiol. 2015;66(6):656-8. doi: 10.1016/j.jacc.2015.05.073

18. de Vries E, Meneses MX, Piñeros M. Years of life lost as a measure of cancer burden in Colombia, 1997-2012. Biomédica. 2016;36:547-55. doi: 10.7705/biomedica.v36i4.3207

19. Wright AK, Kontopantelis E, Emsley R, Buchan I, Sattar N, Rutter MK, et al. Life Expectancy and Cause-Specific Mortality in Type 2 Diabetes: A Population-Based Cohort Study Quantifying Relationships in Ethnic Subgroups. Diabetes Care. 2017;40(3):338-45. doi: 10.2337/dc16-1616

20. Murillo-Zamora E, García-Ceballos R, Delgado-Enciso I, Garza-Guajardo R, Barboza-Quintana O, Rodrígues-Sánchez IP, et al. Regional-level estimation of expected years of life lost attributable to overweight and obesity among Mexican adults. Glob Health Action. 2016;9:31642. doi: 10.3402/gha.v9.31642

21. Costa AF, Flor LS, Campos MR, Oliveira AF, Costa MFS, Silva RS, et al. Burden of type 2 diabetes mellitus in Brazil. Cad Saúde Pública. 2017;33(2):e00197915. doi: 10.1590/0102-311x00197915

22. Garcia LAA, Camargo FC, Gomes THM, Rezende MR, Pereira GS, Iwamoto HH, et al. Production of Nursing knowledge regarding potential life years lost: a bibliometric study. REFACS. 2017;5(1):34-46. doi: 10.18554/refacs.v5i1.1911 